Eastern Illinois University

The Keep

Faculty Research \& Creative Activity

History

August 2008

\title{
"Partisan for the Hard Hats": Charles Colson, George Meany, and the Failed Blue-Collar Strategy
}

Edmund F. Wehrle

Eastern Illinois University, efwehrle@eiu.edu

Follow this and additional works at: http://thekeep.eiu.edu/history_fac

Part of the History Commons

\section{Recommended Citation}

Wehrle, Edmund F., "'Partisan for the Hard Hats": Charles Colson, George Meany, and the Failed Blue-Collar Strategy" (2008).

Faculty Research \& Creative Activity. 23.

http://thekeep.eiu.edu/history_fac/23

This Article is brought to you for free and open access by the History at The Keep. It has been accepted for inclusion in Faculty Research \& Creative Activity by an authorized administrator of The Keep. For more information, please contact tabruns@eiu.edu. 


\title{
"Partisan for the Hard Hats": Charles Colson, George Meany, and the Failed Blue-Collar Strategy
}

\author{
Edmund F. Wehrle
}

On May 5, 1970, Jay Lovestone, the tenacious ex-communist who headed the AFL-CIO's vehemently anticommunist International Affairs Department, arrived for a secret rendezvous with Charles Colson, President Richard Nixon's devoted-to-a-fault aide. A year before, the president assigned Colson the job of cultivating blue-collar workers as part of a grand push to build a broad Nixon coalition for the 1972 election with the potential to reshape American electoral politics. Colson experienced only resistance for almost a year, but Nixon's defiant invasion of Cambodia in the spring of 1970 brought an unanticipated breakthrough. Lovestone simply could not have been more supportive or forthcoming. Nixon, the AFL-CIO foreign policy expert told Colson, was the "first president since Harry Truman to have real guts." Lovestone vowed "to activate all the international resources of the AFL-CIO" in support of the president, and the pair jointly drafted a pro-Nixon statement for the AFL-CIO Executive Council, praising the Cambodian incursion. 1

The Cambodian invasion, in fact, set in motion an awkward, brief alliance between the White House and key leaders of the AFL-CIO. Nixon's "blue-collar strategy" helped him win the 1972 election and, according to some, put a final nail in the coffin of the once-powerful New Deal voting coalition.2 While historians have focused on Nixon's supposedly clever manipulations of the cultural alienation of white urban workers, the president's so-called blue-collar strategy rose overwhelmingly on one issue: the unique politics of the Vietnam War - a war in which the AFL-CIO and many, if not all, of its members had much invested.3 It was largely on the basis of the war that AFL-CIO leaders and many rank-and-file members were drawn temporarily to Nixon. But the war hardly provided a permanent boost to either Nixon or his plans to make over American politics. Indeed, an enduring Democratic coalition and deep misgivings about the president, especially his controversial economic policies, hobbled the blue-collar strategy, which collapsed permanently in 1973, the victim of Watergate and a crumbling economy. Although Nixon did seek to fashion a broad cultural appeal to workers, such entreaties - far from exhibiting any deep understanding of working-class sensibilities were in fact marked by a clumsy, awkward, and ineffectual identity politics. 4 In the end, the blue-collar strategy rose on foreign policy and fell on economics; the president's shoddy cultural campaign remained at best an ill-executed sideshow.

Elected by only the slimmest of margins against a bitterly divided Democratic Party in 1968, Nixon had reason to fear for his political future as he assumed office. Likely to face more unified opposition in the next election, the new president fully understood the imperative of broadening his political base. Already Kevin Phillips, a senior strategist for Nixon's 1968 campaign, and others had outlined strategies for expanding the appeal of the Republican Party. In his book The Emerging Republican Majority, 
Phillips argued the traditional New Deal coalition was well on its way to splintering. Under the pressure of urban chaos and rapid societal change, ethnic and workingclass voters in particular seemed to be straying from the Democratic camp. 5 In the 1968 presidential elections, organized labor in the United States spent a record $\$ 60$ million in support of Vice President Hubert Humphrey, but that painful political year had been rife with signs of tension between organized labor and the Democratic Party. Many labor leaders seethed in resentment against liberals who were slow to support the more hawkishly inclined Humphrey. Meanwhile, those same leaders struggled to thwart blue-collar support for the insurgent George Wallace campaign, the appeal of which went beyond the governor's hostility to civil rights.6 In his righteous anger, Wallace seemed to sum up the anxieties of many workers toward the rapidly changing social and cultural scene. P. L. Siemiller, president of the International Association of Machinists (IAM), for instance, virtually echoed the Wallace line when he told delegates at the 1968 IAM convention that "union members who have worked so hard to build this country are pretty tired of rioters, looters, peaceniks, beatniks, and all the rest of the nuts who are trying to destroy it."7

Nixon had every incentive to try to take advantage of these developments, but besides political opportunity, the new president's odd psychology clearly contributed to his interest in cultivating blue-collar support (and his carelessness in going about it). The product of a humble background that often left him ill at ease in the corridors of power, Nixon bitterly resented those he saw as the intellectual and cultural elite - the media, academia, and liberal power brokers. Instead, he instinctively sympathized with labor leaders, whom he saw as tough, blunt, gutsy, and operating outside the political mainstream. In a private White House meeting with Richard Scammon, coauthor of the influential book The Real Majority, Nixon dwelled "at some length" on his admiration for AFL-CIO President George Meany, who "despite his da's, dem's, and do's would come in, would see a problem, would be willing to have the guts and courage to do what had to be done." By contrast, added the president, "there is not a college professor in the U.S. today whom he could rely upon to have the same perception." 8

From his earliest days in office, then, Nixon sought to cultivate both blueCollar voters and trade union leaders. The president assigned Charles (Chuck) Colson, a self-proclaimed "partisan for the "hard hats," " the task of drawing both rank and file and labor leadership into a planned "new majority" coalition. Central to this job was "squeezing, cajoling and jawboning" Meany, whose support the president particularly coveted. 9

Like Nixon, Colson bore no guiding political philosophy save opportunism and a general resentment of the establishment. He grew up in Boston in lowermiddle- class circumstances. A self-described "outsider to the establishment" and "swamp Yankee," Colson fit in "neither with the new ethnics ... nor the old stock." Of his family, he recalled "acceptance was what we were denied and what we most fervently sought." As a young man, he cut his teeth in the rough-and-tumble world of Boston politics working for liberal Republicans, such as Governor Robert Bradford 
and Senator Leverett Saltonstall.10 No doubt his ideological vacuity and background in urban politics where labor and ethnicity figured prominently primed Colson for his "hard hat" assignment.

Although Meany had a well-deserved reputation as a hawk on Vietnam and rarely missed an opportunity to criticize the antiwar movement, Colson made little headway with the union chief. Nixon himself did not help the cause. At their first White House meeting, Meany found the president annoyingly eager to please and "sort of exuberant, sort of bounding around." As he ushered the labor chief out of the Oval Office, Nixon stopped to introduce his secretary, Rose Mary Woods. "She's a Catholic, too, George," the president commented. The obsequious comment, an example of the president's awkward pandering and unsophisticated identity politics, backfired. Meany later recalled his irritation. "What the hell was that? As if that was important to me! What the hell did I care what she was." Meany had similar trouble warming up to other Nixon officials. Attorney General John Mitchell, Meany complained, greeted him like a "lump of granite, no smile on his face."11

Nor did Nixon's initial foreign policy impress the hawkish Meany. The AFLCIO president complained to National Security Advisor Henry Kissinger that he was "appalled at the lack of discipline in the new administration as evidenced by conflicting statements" on Vietnam.12 Jay Lovestone, head of the AFL-CIO's international affairs department, echoed Meany's concerns, fearing the new "administration would be inclined to flee from the Asian theater" and complaining bitterly of Nixon's "bookkeeping attitude on foreign assistance."13

Colson hardly enjoyed more success with the rank and file. He appears to have whittled away his first several months of work seeking out some grand symbolic event or gesture to attract the interest of blue-collar workers. By the summer of 1970, Colson felt he had seized upon something. "I have finally, after many months of work produced a Catholic, veteran, hard-hat all in one," reported Colson to Press Secretary Ron Ziegler. "He is obviously the answer to all our problems and I can have him jump out of the box any time."14 In Colson's "box" was one Benjamin M. Garcia, who volunteered to drive his ride-on lawnmower from New York City to the White House. There, he planned to deliver a petition signed by one million voters in support for Nixon's policies, after which he apparently planned to cut the South Lawn, possibly with the president on board. Few even among Nixon's supporters could take the scheme seriously. Told of Garcia's plans, Lyn Nofzinger, Republican National Committee communications director, quipped, "It will be a sod thing if this doesn't pan out."15 In the end, Garcia, largely ignored by the media, arrived at the White House only to be met by a presidential aide who accepted the petition. 16

The Garcia escapade reflected the extent to which Colson's blue-collar mission overlapped with another of his charges - that of recruiting the support of supposedly "unmelted" white ethnic communities nestled in urban areas. 17 Informed by an awkward combination of simplistic stereotypes and a rudimentary sense of identity politics, Colson set out to cultivate "nationalities" by appealing to mutually shared 
values - however nebulous. In the case of Italian Americans, for instance, Colson urged the president to ban the Justice Department from using the terms "mafia" and "costa nostra." Before a scheduled White House meeting with leaders of the Sons of Italy, Colson counseled the president to bemoan the "so-called intellectual elite who want to tear down our institutions" and talk "about patriotism generally . . . about this group's devotion to community and family."18 The administration's strategy, it appeared, focused largely on stoking group resentment rather than cultivating any true appreciation of ethnic heritage.

For help, Colson turned to the Republican National Committee's Heritage Groups Division, which supplied him with a thick "set of nationality folders containing statistical data, press and radio listings, nationality organizations, [and a] report of Republican activities within the nationality group."19 Committee officials included a ranking of ethnic groups based on what the group had given to the Republican Party. 20 From there, as he had done with Garcia, Colson searched for some symbol or initiative to promote the administration's commitment to a particular "nationality." For instance, Colson badgered Secretary of Transportation John Volpe for names of qualified Italian Americans to appoint to administration jobs.21

Beyond keeping Colson busy, none of his schemes bore any real fruit. There is no record, for instance, of Volpe responding to Colson's requests. Beyond general incompetence, other roadblocks hampered Colson's progress. The White House's political initiatives, in particular, often seemed to work at cross purposes. Early in his presidency, Nixon's Labor Department had pressed the so-called Philadelphia Plan, designed to reform traditionally nepotistic, racist employment practices in the construction trades industries. Nixon's intent appears to have been to seek African American support and drive a wedge between liberals and labor leaders. Whatever the motive, the Philadelphia Plan, named for a prototype program begun in the city of brotherly love, infuriated labor leaders, who quickly made their displeasure public; the president then began furiously backpedaling. At a meeting with an assembly of construction trades union leaders in the spring of 1970, Nixon awkwardly insisted he favored only a "voluntary approach," not a mandatory, heavily regulated affirmative action program. "While not backing away from our support for the Philadelphia Plan," the president told the assemblage, "we, too, favor these 'home town' solutions." Nixon then obsequiously outlined plans for a committee to "devote attention to one of our great national needs - the need to restore pride in a craft and to promote the dignity of skilled labor."22

The on-again, off-again Philadelphia Plan hardly stood as the only example of poor coordination on the part of the White House's political arm. Alongside the blue-collar strategy, Nixon, in his early days in office, launched a number of initiatives designed to woo traditionally Democratic voters, including Latinos, southern whites, blacks, and urban ethnic voters.23 Yet a similar slovenliness marked each new initiative. By executive order in March 1969, for instance, Nixon created the Office of Minority Business Enterprise, to encourage "black capitalism" programs the president felt sure would be popular among the growing black middle class.24 Just as these 
projects were getting off the ground, however, Nixon short-circuited them with the nomination to the Supreme Court of South Carolinian Clement F. Haynsworth Jr., whose record, to be generous, seemed to reflect ambivalence to desegregation. Nixon and his advisors, of course, designed the Haynsworth and follow-up nomination of Harold Carswell as the centerpiece of another political strategy — that of cultivating white southern support.25

The Haynsworth and Carswell imbroglios were perhaps also an effort to build on a political theme that had worked well for Nixon (and upstart candidate George Wallace) during the 1968 campaign — law and order. Although never specific, Nixon promised strong initiatives aimed at "stopping the rising crime rate and for reestablishing freedom from fear." But the issue faded once Nixon was in office, partly because the Nixonites discovered, as historian Michael Flamm explains, that "controlling crime was more difficult than they [rhetorical advocates of law and order] had led the American people to believe.'26 Short of Nixon aide Bud Krogh's ride-alongs with the Washington, DC, police, the issue received increasingly little attention.27

In many ways, the Nixon administration was pursuing what later critics would identify as the most unfortunate characteristics of identity politics — an essentialist approach in which appeals to gross stereotypes substituted for substantive policy initiatives. But the administration's implementation of its political initiatives proved so ill-executed and transparent that they fell largely on deaf ears. 28

Yet even as the White House and Colson appeared to have hit rock bottom, events already were conspiring in their favor. The catalyst providing sudden life to the blue-collar strategy was Nixon's controversial invasion of Cambodia. The uproar that came with the incursion caught the White House off guard. Killings at Kent State University and Jackson State College clearly rattled the administration. Bitter protests seemed to spring from every corner of the country; however, pro-war elements in U.S. organized labor - located in particular at the helm of the AFL-CIO and in the construction trades unions - deeply appreciated what they saw as tough, appropriate action.29

The hawkishness of the AFL-CIO leadership and many - although by no means all - union members was very much in keeping with the anticommunism of postwar liberalism. Key union leaders, like many liberals committed to international development, believed the Cold War required more than just an arms buildup: it required a holistic commitment to economic, social, and political development in areas of the world threatened by communism. Guided by a sense that such development required, in particular, the development of "free," independent trade unions, organized labor became deeply involved in foreign affairs.30 The AFL, CIO, and subsequent AFL-CIO had established a well-connected network of foreign policy operatives around the world, often working in league with the Central Intelligence Agency and other official U.S. agencies.

As the Cold War shifted to the Third World, so too did the attention of labor's 
internationalists. American laborites first made contact with a nascent trade union movement in Vietnam in 1950. This movement, founded by a group of nationalists disaffected by a brief alliance with the Viet Minh, took the name of the Vietnamese Confederation of Christian Labor (CVTC) in 1953 but shortened the title to Vietnamese Confederation of Labor (CVT) in the early 1960s to reflect its diverse membership.

Relations between U.S. labor and the CVTC solidified when American trade unions contributed financially to help relocate thousands of Vietnamese workers from above the 17th parallel in 1955, following the division of Vietnam produced by the 1954 Geneva Peace Accords. Later, American laborites working through U.S. foreign aid agencies helped the CVT further establish itself in South Vietnam and navigate the shoals and dangers associated with the U.S.-backed Ngo Dinh Diem regime. On several occasions, Meany and Lovestone pressed State Department officials to shield CVT leaders from arrest as the Ngo family grew increasingly mercurial and dangerous. After the coup resulting in Diem's death in 1963, the AFL-CIO sponsored CVT President Tran Quoc Buu's visit to Washington, DC, in the spring of 1964. The highlight of Buu's trip was a personal meeting between himself and President Lyndon Johnson.31

Enthusiastic about the CVT as a vehicle for reform in troubled South Vietnam, the AFL-CIO leadership envisioned the Vietnamese labor organization as everything from the base for mass political mobilization to a paramilitary force around which to rally a reticent population. Motivated by an intense anticommunism and devotion to the CVT, the federation became early, "unstinting" backers of Johnson's war in Vietnam. In 1967, Meany and Lovestone arranged Agency for International Development (AID) sponsorship of a permanent AFL-CIO labor "institute" in Southeast Asia. The Asian-American Free Labor Institute (AAFLI) was to be funded primarily by AID, yet administered independently by the AFL-CIO - similar to other arrangements initiated by U.S. labor and the Kennedy/Johnson administrations in Latin America and Africa.

Having invested tremendous time and energy in Vietnam and never relinquishing hopes that the CVT might become a vehicle for reform and national inspiration, AFL-CIO officials regarded Nixon's election with genuine concern. In the wake of Kennedy's and Johnson's activism, the AFL-CIO leadership feared a retreat to the reactive Eisenhower years and an abandonment of international commitments. Nixon's interest in refocusing foreign aid in particular worried federation officials. The new president, upon taking office, launched plans to reform international aid by creating the Overseas Private Investment Corporation, designed to shift aid administration into private hands.32 The Nixon administration, AFL-CIO Vice President Joseph Bierne warned Meany, risked "losing sight of the social development aspect" of foreign aid, adding, "there can be very little possibility for American labor playing a distinct positive role in international banking mechanisms."33 The AFL-CIO's international labor institutions now appeared imperiled. Having established what amounted to a sweetheart deal with AID under the Kennedy and Johnson administrations, Meany and his circle increasingly feared retaliation under their political 
enemy Nixon.

These concerns hung over Meany as he arrived for his first visit to the Nixon White House - the same meeting where the president had so annoyed him with the comment about his secretary being a fellow Catholic. Despite that road bump, the pair had devoted two-thirds of their meeting to a wide-ranging discussion of the state of the world. Meany lobbied the president "at length about the AFL-CIO program of training union leaders." Gratifyingly, Nixon "expressed interest and support for continuation of the [labor] program."34 Relieved that AAFLI and his other programs were safe, Meany and most labor leaders nevertheless remained wary of Nixon.

However, the president's invasion of Cambodia, in particular his defiant insistence the United States would not act "like a helpless, pitiful giant," suddenly turned everything around. Jay Lovestone was so impressed that he arranged the clandestine meeting with Colson described in the opening of this article. Unbeknownst to Meany, after their initial May 5th rendezvous, Colson and Lovestone began meeting regularly. The two arranged for Nixon personally to brief the federation's Executive Council on Cambodian developments, a briefing at which the president received a particularly warm welcome. 35

As the pair connived, a series of spontaneous pro-war rallies in New York City by so-called hard hat construction workers excited the interest of Lovestone and Colson. The counterdemonstrations began on May 8, when construction workers attacked peace protesters in Manhattan, allegedly in retaliation for an act of desecration against the American flag; related protests quickly flared in other cities.36 In New York City, the hard hats, basking in media attention, began holding daily demonstrations in the city's financial district. Union leaders — in particular ambitious Peter Brennan, president of the Building and Construction Trades Council of Greater New York - seized control of the previously spontaneous protests. 37

In many ways, the hard-hat riots better reflected a general outpouring of worker discontent and militancy than a specific endorsement of Nixon. Already a wave of major strikes had washed across the country. Most notably in late 1969, 147,000 electrical workers walked off their jobs at General Electric for 102 days. The following year, 394,000 members of the United Auto Workers (UAW), demanding double-digit percentage wage increases to counterbalance rising inflation, which the UAW specifically blamed on Nixon, waged a two-month-long bitter strike against General Motors.38 Like the rest of the country, blue-collar workers seemed swept up in an ill-focused spirit of rebellion.

Yet to Colson and Lovestone, the hard hat rallies offered an alluring political opportunity to counterbalance flaring antiwar protests around the country. Through Lovestone, Colson urged Brennan and others to organize a major, highly publicized, pro-war rally to be held May 20 simultaneously in several cities. Hard hat leaders needed little prompting. Brennan and construction union leaders eagerly organized the massive demonstration.39 In New York City, the May 20 march drew between 
100,000 and 150,000 protesters; smaller rallies took place in San Diego, Pittsburgh, Buffalo, and other cities. 40

In an overt effort to align himself closer with the hard-hat demonstrations, Nixon invited its organizers to the White House for a "serious, in-depth briefing on the situation in Cambodia." As cameras snapped, Brennan presented Nixon with a hard hat, a "symbol of our support for our fighting men and for your efforts in trying to bring the war to a proper conclusion." Emotions swelled when Michael Donovan, a member of the Executive Committee of Brennan's Building and Construction Council whose son had died in Vietnam, approached Nixon. "Mr. President," he said, "if someone would have had the courage to go into Cambodia sooner, they might have captured the bullet that took my son's life." The president appeared "visibly moved." 41

Expedited by deep, painful divisions over the Vietnam War, Colson appeared on the verge of achieving his mission. Following the visit to the White House by the hard-hat leadership, the Nixon administration's "political cultivation of labor" shot into high gear. Nixon invited seventy labor leaders and their wives, including the Meanys, to an elegant Labor Day dinner on September 7, 1970.42 The Nixonites specifically targeted the Meany family for "cultivation." H. R. Haldeman suggested that Meany's daughters "be given a certain amount of play" and be included "in Mrs. Nixon's tea for the wives of labor leaders." 43 In October, Nixon summoned Meany, AFL-CIO European agent Irving Brown, and Lovestone to the White House for a "national security briefing." 44 In December, Nixon met personally with AFL-CIO Vice President Joseph Keenan, who had journeyed to Vietnam in 1967 to help launch AAFLI. White House staffers, drawing on an inchoate identity politics, noted opportunistically that Keenan "is a devoted Catholic and important labor leader, and is moving away from the Democrats." 45 White House officials gloated over the progress they believed they made. H. R. Haldeman called the high-profile Labor Day dinner "a real coup." 46

Yet such gestures resonated less with labor leaders than with White House staffers. AFL-CIO Public Relations Director Albert Zack, for instance, bemoaned the Labor Day dinner as "politically motivated. It was all a part of the blue collar strategy." 47 Likewise, in responding to Nixon's entreats, Meany was playing his own game of hardball politics. The implied threat of an alliance with Nixon provided the AFL-CIO with political leverage as it sought to push the Democrats toward labor's agenda. Noting Nixon's "pitch," Meany warned the Washington Post that the Democratic Party needed to rid itself of "extremists" on the left.48 Clearly Meany sought to enhance the AFL-CIO's "broker" role and move the Democratic Party back toward its traditional anticommunism. 49

Aside from political wooing, blue-collar strategists made at least a half-hearted stab at policy initiatives aimed at blue-collar workers. Assistant Secretary of Labor Jerome Rosow issued a report in March 1970 entitled "The Problem of the BlueCollar Worker," prescribing tax relief, subsidized housing, expanded public 
transportation, and educational grants for the lower-middle class.50 But Nixon showed little interest in the initiatives, ordering only "some initial implementation of the Rosow blue collar report even if it is only symbolic." 51 Still, by the fall of 1970 , Colson was positively gleeful. "The ground is plowed to bring them [organized labor] into the fold," he pronounced.52

In reality, however, Nixon had made little headway. Neither Nixon's cultural outreach campaign nor his invasion of Cambodia appeared capable of cutting the apron strings between the Democratic Party and union members - as the results of the 1970 congressional elections quickly made manifest. In the buildup to the election, defying Nixon's courtship, trade unions and the rank and file pumped millions of dollars into the campaign coffers of Democratic candidates, a trend that was "interpreted by many labor leaders that blue collar workers are not turning conservative."53 That November Democrats added nine seats to their majority in the House of Representatives and three seats in the Senate. "GOP Aimed Campaign Strategy at Wrong Group" blared a Washington Post headline in the election's aftermath. Noting the success of Pennsylvania gubernatorial candidate Milton Shapp, who won 91 percent of the labor vote, pollster George Gallup concluded that Nixon had bet too much that the "hard hat or otherwise was angry, frustrated and bitter at national conditions and ready to switch parties." Economic priorities stressed by Democrats, Gallup explained, had triumphed over the amorphous "law-and-order" cultural campaign mounted by Republicans for union voters.54 If any in the White House had thought their cultural campaign was making headway, they now had definitive evidence to the contrary.

Angered by the election results, some in the White House called for the abandonment of the blue-collar strategy. Nixon's chief speechwriter, Jim Keogh, labeled Colson's work "a mistake" and complained that after the Labor Day dinner, union bosses "went out and bludgeoned us with rhetoric and money." Worse, he argued, the Colson mission was fatally flawed in its assumption that union leaders and members saw things the same way. "I hold the belief," insisted Keogh, "that even rank-and-file labor union members tend to look with suspicion on big labor leaders."55

The blue-collar strategy that had briefly taken flight following the Cambodian invasion now lay in ruins by the end of 1970 - and the following year was to bring no revival. As U.S. troop withdrawals quickened, the war in Indochina "virtually disappeared as a campaign issue."56 For organized labor, a new crisis took center stage - the sliding economy. In 1971, unemployment shot up almost two percentage points to approach 6 percent. Meanwhile, stagflation — stagnant wages and rising prices - first reared its ugly head as the cost of living inched upward, accompanied by rising unemployment. The hard hats were hardest hit. By mid-1971, unemployment among construction workers stood at twice the national average with some trades edging toward 50 percent unemployment.57

The souring economy became a bone of bitter contention between Nixon and almost the entire organized labor movement. Meany, insisting that "the only game plan for America is full employment," relentlessly flayed Nixon's handling of 
the economy, prescribing instead expanded federal spending to address the downturn. 58 Within the White House, however, organized labor increasingly became a fall guy for inflation and economic trouble. "Our problems come because of the high wages demanded by the workers of this country," complained White House eco nomic advisor Arthur Burns.59 Likewise, Council of Economic Advisors Chairman Paul McCracken worried "the construction industry continues to cause us extremely serious problems in our attempts to reduce inflation. Wage increases appear to be accelerating instead of subsiding." 60 Far from cultivating labor, some in the Nixon administration increasingly moved to scapegoat blue-collar workers.

Nixon's August 1971 announcement of price and wage controls further fueled mounting hostility between labor and the White House. To many trade unionists, the announcement seemed a negation of a key principle of postwar liberalism — "full employment," an offshoot of Keynesian economics, in which aggressive fiscal spending became the prescription for economic growth. As such, Meany promptly positioned himself as the leading critic of price and wage controls. He pounded the Nixon plan as "an assertion of dictatorial power completely foreign to the American concept of freedom." 61 When Nixon appeared before the AFL-CIO biannual convention in November 1971, Meany and the assemblage was dismissive, borderline rude, to the president.62 For more than a year, Meany spewed venom at Nixon, at one point calling the plan "a tax bonanza to American corporations at the expense of American workers." 63 His attacks on Nixon drew rare praise from the media in the process. Meany graced the cover of both Time and Life magazines. "At 77," waxed Life magazine columnist Hugh Sidey, "George Meany has been reborn." 64 Even his enemies in the labor movement marveled at his new lease on life. "George is acting the great trade union leader he is capable of being. . . . If this fine man could reconcile himself to the idea that the war is one of the blackest pages in America's history, he would soon develop into one of the best loved labor leaders in the world," privately noted Patrick Gorman, the adamantly antiwar president of the Amalgamated Meat Cutters and a frequent Meany critic. 65

Watching his cultivation campaign sputter, Colson angrily blamed the press for "trying their best to drive a wedge between labor and ourselves." He urged Nixon to let Meany "know that the door remains open." 66 Yet other factions in the White House demanded the door be slammed shut. Special Assistant to the President Desmond Baker circulated a caustic memo assailing Meany as "so interested in seeing the Democratic Party recapture the White House in 1972 that he will oppose President Nixon whatever he does." 67 White House staffers convened a special meeting to coordinate a response to Meany's attacks. The ad hoc committee, which included Colson (now evidently ready to take a harder line), George Shultz, Haldeman, and Treasury Secretary John Connally, resolved to freeze Meany out; the president "should not at this time engage in any further dialogue with Meany privately or publicly." In public, the administration would seek to "deliberately isolate Meany. . . . This effort if properly done could separate Meany from his membership." 68

The nadir between Nixon and the AFL-CIO came in March 1972, when a 
truculent Meany made a public show of angrily quitting the president's Pay Board, the agency that oversaw the administration's economic controls program.69 Embittered by Meany's continuing hostility, Colson decided to abandon completely the carrot and reach for the stick. He asked White House aide General Alexander Haig to conduct an "exhaustive" review of federal funds "squirreled away in various accounts" designated for AFL-CIO international programs. "I have no problem if the AFLCIO finds out what the White House is asking," added Colson. "In fact, that might be very salutary under the circumstances of Mr. Meany's present silence on international issues and the vicious attacks on the President on domestic issues."70 The message was pure blackmail: future outspokenness would imperil labor's overseas initiatives, including AAFLI. Haig's investigation revealed roughly \$6 million earmarked for AFL-CIO's 1972 foreign operations, with \$1.6 million designated for AAFLI.71 Meany's continuing attacks on Nixon now jeopardized the federation's generous government subsidies.

Yet even as tensions threatened to boil over, Vietnam remained a point of commonality between the administration and many in organized labor. In 1971, for instance, on the eve of a national presidential television address on Vietnam, National Security Advisor Henry Kissinger journeyed the several blocks between the White House and AFL-CIO headquarters to privately brief Meany on the contents of the speech. "I know you've got your problems on the economy but we appreciate your support in this area," Kissinger told the labor chieftain. "It involves the fabric of our country and maybe, if we do not succeed, the country won't be worth being President of." Meany readily concurred and complained of the damage done by recent revelations regarding the My Lai massacre - "the result of this peacenik-sort of pounding of the press," according to the labor chief. Meany and Kissinger then swapped stories about facing down antiwar demonstrators on college campuses, Kissinger at MIT and Meany at Randolph-Macon College. "I think the professors are worse than the students," opined Meany to the former Harvard University faculty member. 72 In the face of stiffening opposition to the war, the administration and the AFL-CIO leadership still relied upon each other for mutual support.

Trouble in Vietnam, in fact, brought the first inklings of life back to the bluecollar strategy in a year and a half. On March 30, 1972, the North Vietnamese army launched the Easter Offensive, a conventional military invasion of the South, designed to capitalize on diminishing U.S. combat strength. For several weeks the fate of South Vietnam hung in the balance. Finally Nixon turned the tide by unleashing a massive bombing campaign, code named Linebacker I. During the bitter fighting, North Vietnamese imprisoned or killed some thirty lower-level CVT officers and left thousands of CVT families homeless. In the hard-hit border province of Binh Long, about 50 miles north of Saigon, the invaders murdered the entire CVT provincial leadership. Struggling, South Vietnamese labor called upon the AFL-CIO for help, and Meany responded immediately with an emergency cash grant.73 The AFL-CIO Executive Council ominously warned that the outcome of the battle for South Vietnam would "affect profoundly the destiny of our country."74 As the country moved into an election 
year in 1972, Vietnam emerged as the litmus test for the AFL-CIO president. Asked by an interviewer if he wanted to see Nixon beaten, Meany responded, "I don't want to see him defeated by somebody who is advocating surrender. I don't believe in surrender in Vietnam."75

Determined to preserve its hawkish agenda in Vietnam (still very centered on supporting the struggling CVT), the AFL-CIO saw few attractive options among Democratic presidential contenders. Key figures in the party, in the minds of many in organized labor, seemed to have forsaken the Cold War anticommunism of postwar liberalism. Even old stalwart Hubert Humphrey, labor's champion in 1968, had turned sharply against the Vietnam War, as had the 1968 Democratic nominee for vice president, Senator Edmund Muskie, also a contender for the 1972 nomination. Federation hopes rested solely with Washington Senator Henry Jackson, an increasingly rare liberal cold warrior who remained committed to a "full employment" agenda but still took a hard line on Vietnam. By spring, however, the worst case scenario came to pass: Senator George McGovern, unapologetically demanding immediate withdrawal, overwhelmed Humphrey, Muskie, and Jackson in the Democratic primaries.

The AFL-CIO leadership recoiled at McGovern's swift march to the Democratic nomination. "My right arm will wither before I vote for a McGovern," Lovestone told Colson.76 Compared to Nixon, of course, McGovern's record, although hardly gleaming, was prolabor. His position on Vietnam, however, rendered him untenable to the federation. Moreover, the South Dakotan not only advocated immediate withdrawal, he vocally rejected wholesale the anticommunist, Cold War agenda. In a 1971 fund-raising letter that much concerned AFL-CIO staffers, McGovern suggested that retreat from Vietnam would mark only the beginning of his crusade to "free" the country "from the last vestiges of cold war paranoia." Seeming almost to delight in offending the ardent anticommunist sensibilities of Meany and his circle, McGovern told an interviewer, "I think communism is another economic system that doesn't happen to fit my view of how society ought to be organized, but I'm willing to live in a world of diversity."77

George Meany was not willing to "live in a world of diversity." Seeking to "rescue" the Democratic Party, Meany held a "secret meeting" with Senator Ted Kennedy in May. He urged the Massachusetts senator, whom Meany considered "the lesser evil," to enter the race. 78 Kennedy, however, demurred, and the Democratic convention that year only confirmed to Meany how much ground labor had lost. Union leaders found themselves unwanted guests as young activists swarmed the convention, treating their elders with barely concealed contempt. Calls for immediate withdrawal from Vietnam echoed throughout the convention hall. Political ground had shifted dramatically, and labor now found itself on hostile terrain at a Democratic Party convention. Party insurgents and labor regulars seemed almost unrelated species. Labor delegates complained bitterly they were treated rudely and dismissively by the McGovernites planning the convention. Surveying the scene at Miami Beach, Meany lamented the Democratic Party's seizure by "people who looked like Jacks, 
acted like Jills, and had the odor of Johns about them."79

Out of the ashes of the labor-liberal alliance rose a revived blue-collar strategy. A few days after the Democratic convention, the AFL-CIO Executive Council voted, 27 to 3, to abstain from issuing an endorsement. President Nixon greeted the news enthusiastically as carrying the "potential of becoming one of the most important developments of the 1972 campaign." 80 Already Nixon had received the endorsement of the renegade Teamsters Executive Council, delivered personally by the council to the president at a poolside reception in San Clemente.81 Roughly a week later, Meany joined Nixon, Secretary of the Treasury George Shultz, and Secretary of State William Rogers for a well-publicized round of golf, ending a year and a half of bitter sniping between plumber and president. On the links, Meany assured Nixon of his neutrality.82 The friendly game combined with Meany's known contempt for McGovern amounted to a Nixon endorsement.

Meany grew increasingly annoyed as McGovern's unfolding campaign showed no sign of moderation (while revealing ample signs of disorganization). Following the well-managed Republican convention, Meany asked George Shultz for a private meeting. Avoiding a direct endorsement, the AFL-CIO president carefully reviewed for Nixon's treasury secretary how the president might appeal to trade unionists. Despite his doubts about détente (of which he always remained a critic), Meany thought Nixon to be "perfect on foreign policy." Although a supporter of civil rights, Meany explained he had come to appreciate Nixon's reservations on busing. On the controversial topic of defense spending, the AFL-CIO president, a strong proponent of Keynesian spending, commended the president for emphasizing national security without connecting the issue to jobs. Workers, Meany explained, understand the importance of defense spending, but to speak openly about its economic impact would "just undermine the national security argument." In the margins of John Ehrlichman's transcript of the meeting, Nixon scribbled "right" alongside Meany's advice.83 Still, Nixon, eager to make defense spending an issue to attract working Democrats, ordered the Defense Department to prepare a general report on the relationship between military spending and economic growth. The resulting study, The Economics of Defense, essentially made the case for military Keynesianism by predicting difficult times should McGovern get his defense cuts.84 In stump speeches, Nixon, adopting Meany's counsel, never openly linked defense spending and employment, but the Defense Department's report performed that task for the president. The issue of defense jobs, clearly related to the AFL-CIO's full-employment economic strategy and the war in Southeast Asia, hung over the campaign.

His blue-collar strategy rising like the phoenix, Colson scrambled again to shore up a cultural appeal to the nation's workers. Again, he relied heavily on a supposedly charismatic figure to rally support. In the summer of 1972, the Nixon campaign hired Michael Balzano, "an ex-garbage collector who worked his way nights to a Ph.D." to cement ties with "ethnic and blue-collar areas." Colson assured the president Balzano was "a solid man" who knew "how to relate to Middle American constituencies." 85 
With the dubious weight of Colson and Balzano behind him, Nixon did win the bulk of the blue-collar vote in November, winning 57 percent of voters from union households.86 Yet the loyalties of blue-collar voters remained more "fluid" than Nixon might have liked, and, reflecting the limits of the blue-collar strategy, workers did not favor Republican congressional candidates. Many split their ballots between a Republican president and Democratic Congress - hardly a dramatic political realignment, or the passing of postwar liberalism.87 The Democratic Party, concluded U.S. News and World Report, in the wake of Nixon's victory, "at the grass roots, demonstrated that it is still a strong majority party." Republicans lost two senate seats, and despite pickups in the House, still faced a strong Democratic majority. "It was a personal triumph for Mr. Nixon," mused RNC Chairman Robert Dole, "not a party triumph." 88

Still with his "personal triumph," Nixon continued to press his blue-collar strategy. He appointed as secretary of labor Peter Brennan, president of the Building and Construction Trades Council of Greater New York and organizer of the Manhattan hard-hat rallies. The president also revived his courtship of labor leaders. When the January 1973 Paris Accords finally ended direct U.S. involvement in Vietnam, Nixon sent Meany an appreciative note: "Now that we have finally achieved peace with honor in Vietnam, I particularly want you to know how much I have appreciated the support you have given during these difficult years to the policies that made that achievement possible. ... history will prove you have been right." 89

Without the Vietnam issue, however, the blue-collar strategy quickly lost its potency. Severe stagflation, ironically seen by many economists as the result of Vietnam-era spending habits, rippled across the nation in 1973. The Nixon-labor dalliance unraveled yet again amid bitter exchanges over the handling of the economy and the brewing Watergate scandal. At the tenth biannual AFL-CIO convention, in October 1973, delegates unanimously demanded Nixon's resignation. Meanwhile, the AFL-CIO's relations with Secretary of Labor Peter Brennan deteriorated to such an extent that Meany insisted on conducting business solely with Secretary of Treasury George Shultz, whom he regarded as more competent and someone with the president's ear.90

In the wake of Watergate and the economic collapse of 1973, the blue-collar strategy essentially died - mourned by virtually no one. Hardly the product of "cultural vision" or sensitivity to supposedly underlying class tensions, the blue-collar strategy was less sophisticated, ultimately operating only in fits and starts. The unique politics of the Vietnam War, in particular the AFL-CIO's heavy investment in a South Vietnamese labor movement, briefly enlivened the strategy and (alongside the incompetence of the McGovern campaign) perhaps helped Nixon win the 1972 election. With the Vietnam issue removed from the table briefly in 1971 and then permanently in 1973, the strategy — for both union leaders and the rank and file — floundered. Never again would trade union leaders come as close to endorsing a Republican president as they had in 1972. 
Some have argued that Nixon's blue-collar strategy set the stage for the rise of the so-called Reagan Democrats a decade later - that while the president failed in cultivating the leadership, he made gains with the rank and file.91 But the 1970 and 1972 elections hardly suggested potential realignment. Rather, the majority of workers and trade union leaders remained wedded to the postwar liberal agenda of activist anticommunism abroad and full-employment economics at home. Facing McGovern in 1972, Nixon essentially seized that agenda by promising a strong foreign policy and promoting military Keynesianism. Beyond this, Nixon never made a serious attempt to overcome the cultural and ideological gulf separating him and the organized labor movement, and never moved to provide working families with any serious safeguards as they entered a period of prolonged economic challenges. Without the Vietnam War, the blue-collar strategy would have remained a figment of Charles Colson's imagination - and even with the war, it proved to be little more.

Revisionists who praise Nixon's cultural sensitivity are correct on at least one account: the president and his political advisors did think inordinately in terms of group identity - and they were hardly alone. By the late $1960 \mathrm{~s}$, many on the far left no longer adhered to the once-ubiquitous principles of liberal universalism - the belief that all, regardless of race, gender, or ethnicity, shared an essential common humanity. Instead of moving beyond group identity, advocacy groups for African Americans, women, and others began espousing a new politics grounded in group membership. Identity politics remains the dominant political philosophy of our times. Nixon obviously shared little in common with most of this rising mentality.92 Yet in his political machinations - often grounded in simplistic stereotypes such as in the case of the blue-collar strategy - Nixon and his aides engaged the worst elements of identity politics.93

\section{Footnotes}

1. Charles Colson, "Memorandum for H. R. Haldeman," May 5, 1970, box 78, White House Special Files, Staff Member and Office Files, Charles Colson, Nixon Presidential Materials, National Archives, College Park, MD (henceforth NA). On Lovestone's journey from leader of the American Communist party to vehement anticommunist see Ted Morgan, A Covert Life: Joy Lovestone, Communist, Anti-Communist, and Spymaster (New York: Random House, 1999).

2. "Smashed in the 1972 election — and perhaps forever — was the old coalition of big city machines, the South, blacks, labor unionists, and ethnic voters, conceived by Franklin D. Roosevelt," concluded U.S. News and World Report in "The Way People Voted and Why," November 20, 1972. Also see "Splintering the Great Coalition," Time, November 20, 1972, which drew the same conclusion about the significance of Nixon's victory. Contemporary historians and political scientists have picked up this depiction. See, for instance, Michael Schaller and George Rising, The Republican Ascendancy: American Politics, 1968 -2001 (Wheeling, IL: Harland Davidson, Inc., 2002), 155. Schaller and Rising assert that Nixon brought an "end to the Democratic age 
that had begun in 1932" and set in motion "an era of GOP ascendancy." Also see William Berman, America's Turn Right: From Nixon to Clinton (Baltimore, MD: Johns Hopkins University Press, 1998), 17; Otis Graham, "Liberalism after the Sixties: A Reconnaisance," in The Achievement of American Liberalism: The New Deal and Its Legacies, ed. William Chafe (New York: Columbia University Press, 2003), 305; and Thomas and Mary Edsall, Chain Reaction: The Impact of Race, Rights, and Taxes on American Politics (New York: W. W. Norton, 1992), 21. The Edsalls see the 1972 campaign as marking the rise of a new "Republican coalition."

3. Jefferson Cowie, "Nixon's Class Struggle: Romancing the New Right Worker, 1969 1973," Labor History 43 (2002): 257 - 83. Cowie posits Nixon as "one of the most class aware presidents of the postwar era" who sought to "reimagine the meaning of the American working class" through appeals to "whiteness" and "machismo." To his credit, Cowie does ask "[w]ithout Vietnam, one wonders whether the 'common man' strategy would have survived the trial stage," but concludes that Nixon's blue-collar strategy was "as much a domestic political and moral crusade as an international one." Also see David Greenstone, Labor in American Politics (Chicago: University of Chicago Press, 1977), xxv; and Robert Mason, Richard Nixon and the Quest for a New Majority (Chapel Hill: University of North Carolina Press, 2004), 235. Like Cowie, historian Robert Mason sees Nixon's campaign to broaden his political base as "thoughtful," arguing that the president "carefully analyzed social and political trends." These scholars, of course, are part of a larger group of "Nixon revisionists" that includes Joan Hoff, Dean Kowlowski, Melvin Small, and Brooks Flippin, among others. If not positing Nixon as an outright progressive or liberal, revisionists at least credit him with using liberal policies and politics to divide his opposition. This article argues that in the realm of labor relations and politics, Nixon's initiatives were inept and half-hearted and his political machinations ill conceived and ineffective.

4. See Courtney Jung, "Why Liberals Should Value 'Identity Politics,' " Daedalus 135 (Fall 2006): $32-41$, for a thoughtful discussion of the nature of identity politics.

5. Kevin Phillips, The Emerging Republican Majority (New Rochelle, NY: Arlington House, 1969). Also see Richard Scammon and Benjamin Wattenberg, The Real Majority (New York: Coward-McCann, 1970).

6. Victor Riesel, "Inside Labor," November 6, 1968 (column first appeared in the New York Post); Theodore White, Making of the President 1968 (New York: Atheneum, 1969), 364 - 66. For an effective analysis of Wallace's appeal to working people, see Michael Kazin, The Populist Persuasion: An American History (New York: Basic Books, 1995), $221-42$.

7. As quoted in Kazin, Populist Persuasion, 224.

8. "Memorandum for the President's Files," January 28, 1970, box 24, White House Special Files, Staff and Office Files, Charles Colson, Nixon Presidential Materials, NA. Also see William Safire, Before the Fall: An Inside View of the Pre-Watergate White 
House (New York: Doubleday, 1975), $588-89$.

9. J. F. Lehman to General Haig, May 15, 1972, box 828, Nixon Presidential Materials, NA.

10. Charles Colson, Born Again (Old Tappan, NJ: Chosen Books, 1976), 24 - 29.

11. Archie Robinson, George Meany and His Times (New York: Simon and Shuster, 1981), 279.

12. "Memorandum for the President," April 8, 1969, National Security Council Files, Name Files, box 828, Nixon Presidential Materials, NA.

13. "Minutes of the Annual Meeting of the Board of Trustees of the Asian-American Free Labor Institute held on Monday, February 23, 1970," 67/24, Meany Papers, George Meany Memorial Archives, Silver Spring, MD (hereafter GMMA). Jeffrey Kimball, Nixon's Vietnam War (Lawrence: University of Kansas Press, 1998), 104;

"Memorandum of Conversation," April 8, 1969, National Security Council Files, Name Files, box 828, Nixon Presidential Materials, NA.

14. Colson to Ron Ziegler, August 24, 1970, box 122, White House Special Files, Staff Member and Office Files, Nixon Presidential Materials, NA.

15. Benjamin M. Garcia to George T. Bell, August 12, 1970, box 122, White House Special Files, Staff Member and Office Files, Charles Colson, Nixon Presidential Materials, NA; Eric Brosch, "On This Day in the Nixon Administration," MotherJones.com, September 24, 2003, www.motherjones.com/news/ update/2003/09/we_527_01.html.

16. George Bell memorandum, September 18, 1970, box 67, White House Special Files, Staff Member and Office Files, Charles Colson, Nixon Presidential Materials, NA.

17. For a thoughtful treatment of the growing awareness of ethnicity in American society, see Michael Novak, The Rise of the Unmeltable Ethnics: Politics and Culture in the Seventies (New York: MacMillian, 1972).

18. Colson to Nixon, September 11, 1970, box 21, White House Special Files, Staff Member and Office Files, Charles Colson, Nixon Presidential Materials, NA.

19. Laszlo Pasztor to Colson, July 22, 1970, box 21, White House Special Files, Staff Member and Office Files, Charles Colson, Nixon Presidential Materials, NA.

20. Pasztor to Hugh Sloan, July 15, 1970, box 21, White House Special Files, Staff Member and Office Files, Charles Colson, Nixon Presidential Materials, NA.

21. Colson to Secretary Volpe, July 14, 1970, box 21, White House Special Files, Staff 
Member and Office Files, Charles Colson, Nixon Presidential Materials, NA.

22. "Memorandum for the President," March 23, 1970, box 20, White House Special Files, Staff and Office Files, Charles Colson, Nixon Presidential Materials, NA.

23. On Nixon's coalition-building initiatives see Paul Frymer and John David Skrentny, "Coalition-Building and the Politics of Electoral Capture during the Nixon Administration: African Americans, Labor, Latinos," Studies in American Political Development 12 (Spring 1998): $131-61$.

24. Frymer and Skrentny, "Coalition-Building," 145; Dean Kotlowski, "Black Power Nixon Style: The Nixon Administration and Minority Business Enterprise," Business History Review 72 (1998): 409 - 45.

25. Mason, Richard Nixon, 54 - 55. Robinson, George Meany and His Times, 283. Meany, a moderate liberal on the issue of civil rights, also expressed outrage at the Haynsworth nomination, which the AFLCIO president described as a "declaration of war." When the Senate voted down Haynsworth, Meany complained bitterly that the next nominee, Judge Harold Carswell, had a "record as a racist . . . worse than that of Haynsworth."

26. Michael W. Flamm, Law and Order: Street Crime, Civil Unrest, and the Crisis of Liberalism in the 1960s (New York: Columbia University Press, 2005), 173, 180.

27. Charles Stuart, Never Trust a Local: Inside the Nixon White House (New York: Algora, 2005), 52.

28. For critiques along these lines of identity politics see Todd Gitlin, The Twilight of Common Dreams: Why America Is Wracked by Culture Wars (New York: Henry Holt, 1996), 101; David Hollinger, Post-Ethnic America (New York: Basic Books, 1995), 128 - 29; Brian Barry, Culture and Equality: An Egalitarian Critique of Multiculturalism (Cambridge, MA: Harvard University Press, 2001), 5; for a spirited defense of identity politics see Jung, "Why Liberals Should Value 'Identity Politics.' ",

29. Both the rank and file and leadership of the Teamsters (although Vice President Harold Gibbons was a notable exception) and maritime trades unions tended to be hawkish. More dovishly inclined unions included the United Auto Workers, the Amalgamated Clothing Workers, and Amalgamated Meat Cutters and Butcher Workmen of America. On divisions within the U.S. trade union movement over the Vietnam War see Edmund F. Wehrle, "Between a River and a Mountain": The AFL-CIO and the Vietnam War (Ann Arbor: University of Michigan Press, 2005), 112 - 15, 123 - 26, 157 $-60,176$. On antiwar trade unionism see Philip Foner, U.S. Labor and the Vietnam War (New York: International Publishers, 1988).

30. See, for instance, Ronald Radosh, American Labor and U.S. Foreign Policy (New York: Random House, 1969); Beth Sims, Workers of the World Undermined (Boston: 
South End Press, 1992); Frederico Romero, The United States and the European Trade Union Movement, 1944 -1951 (Chapel Hill: University of North Carolina Press, 1992); Ronald Filippelli, American Labor and Postwar Italy, 1943 -1952 (Palo Alto, CA: Stanford University Press, 1989); and Elizabeth McKillen, Chicago Workers and the Quest for a Democratic Diplomacy, 1914-1924 (Ithaca, NY: Cornell University Press, 1995); all take a dim view of organized labor's foreign policy. A limited work that provides a more positive appraisal is Philip Taft, Defending Freedom: American Labor and Foreign Affairs (Los Angeles: Nash Publishing, 1973).

31. For a full treatment of the relationship between the AFL-CIO and the CVT see Wehrle, "Between a River and a Mountain."

32. "Special Message to Congress on Foreign Aid," May 28, 1969, in Public Papers of the Presidents of the United States: Richard M. Nixon. Vol. 1: 1969 (Washington, DC: U.S. Government Printing Office, 1974), $411-12$.

33. Beirne to Meany, October 5, 1970, 2/17, Lovestone Papers, GMMA.

34. George Schultz, "Memorandum for the Files, Re: Meeting of the President with George Meany and Secretary Schultz, March 13, 1969," box 16, Office of Secretary of Labor, George Shultz, General Records of the Department of Labor, Record Group 174, NA.

35. Colson, "Memo for the President, Subject: Meeting with Executive Council of AFLCIO," May 12, 1970, box 20, Office of Secretary, James D. Hodgson, 1970 -1971, General Records of Department of Labor, Record Group 174, NA; Colson, "Memorandum for President's Files," March 15, 1970, box 20, Office of Secretary, James D. Hodgson, 1970 -1971, General Records of Department of Labor, Record Group 174, NA. Nixon met earlier that spring with the presidents of the AFL-CIO Building Trades Unions. Discussion topics included Laos and Vietnam.

36. New York Times, May 13, 1970; Mark Linder, Wars of Attrition: Vietnam, the Business Roundtable, and the Decline of Construction Unions (Iowa City: Fanpihua, 1999), 277.

37. New York Times, May 21, 1970. A University of Michigan student watching the hard-hat demonstrations commented, "If this is what the class struggle is all about there's something wrong somewhere." Brennan did seek to control some of the violence that marked early hard-hat protests, urging his ranks, for instance, not to act like "red necks." For a cultural analysis of the hard-hat demonstrations, see Joshua Freeman, "Hardhats: Construction Workers, Manliness, and the 1970 Pro-War Demonstrations," Journal of Social History 26 (1993): 725 - 44. Freeman interprets the hard-hat demonstrations as "built on earlier struggles against employers and integration." But the Vietnam War clearly triggered deeper, long-term resentments. "Here were these kids, rich kids, who could go to college, who didn't have to fight, they are telling you your son died in vain. It makes you feel your whole life is shit, just nothing," explained one trade unionist quoted 
by Freeman. Linder, Wars of Attrition, 287, argues that the demonstrations must be seen in "context of the joint state-employer efforts to control construction wages." Depicting a Nixon administration-led conspiracy as behind the hard-hat protests, Linder imaginatively portrays the demonstrations as part of a successful campaign against construction trade workers.

38. "The Blue Collar Worker's Lowdown Blues," Time, November 9, 1970. Maria Abarca, " 'Discontented but Not Inevitably Reactionary': Organized Labor in the Nixon Years" (PhD diss., University of Massachusetts, 2001), 91, 121 - 27, 141- 42. Radical students at the University of Michigan did rally to the cause of the UAW but often alienated striking workers by brandishing slogans like "Smash GM" and by referring to GM as a "racist, war maker."

39. Flyer for Building Trades Rally, May 20, 1970, box 20, Office of Secretary, James D. Hodgson, 1970 -1971, General Records of Department of Labor, Record Group 174, NA. Brennan, in flyers prepared for the demonstrations, portrayed the rallies as aimed at a broad spectrum: "All Americans are invited to join us, students and workers - long hair or short — bald or bearded. Just bring your love for the only flag we have."

40. "Memorandum for the President, Subject: Meeting with representatives of the Building and Construction Trades Council of Greater New York," n.d., box 20, Office of Secretary, James D. Hodgson, 1970 -1971, General Records of Department of Labor, Record Group 174, NA.

41. "Memorandum for the President's Files, Subject: Building and Construction Trades Meeting with the President," May 26, 1970, box 20, Office of Secretary, James D. Hodgson, 1970 -1971, General Records of Department of Labor, Record Group 174, NA. John Dean, Blind Ambition: The White House Years (New York: Simon and Schuster, 1976), 36. The hard hat White House visit drew controversy when Scanlon's Monthly published charges that "racketeers" had been among those invited. Subsequent investigations by the FBI revealed that "shady characters" indeed had been invited with the group.

42. “Dinner Date on Labor Day,” National Journal, January 30, 1971.

43. Haldeman memorandum for Colson, September 14, 1970, box 38, White House Central Files, Confidential Files, Nixon Presidential Materials, NA. Haldeman further targeted Meany's secretary, Virginia Tehas, as also "very important" to the "cultivation" campaign.

44. Colson, "Memorandum for the President, Subject: Meeting with George Meany et al., " handwritten notes of October 13, 1970, meeting, box 22, Office of Secretary, James D. Hodgson, 1970 -1971, General Records of Department of Labor, Record Group 174, NA. Meany used the occasion to lobby for more and better State Department labor attachés. In response, Nixon ordered his secretary of state to conduct an immediate review of the attaché program. 
45. "Open Hour at the White House," December 21, 1970, box 22, Office of Secretary, James D. Hodgson, 1970 -1971, General Records of Department of Labor, Record Group 174, NA; Robinson, George Meany and His Times, 279.

46. H. R. Haldeman, The Haldeman Diaries: Inside the Nixon White House (New York: G. P. Putnam's, 1994), 191- 92.

47. "Dinner Date on Labor Day,” National Journal, January 30, 1971.

48. Neil Gilbride, "Meany Fears Left Seizing Democrats," Washington Post, August 31, 1970.

49. On the AFL-CIO's "desire to maintain the power-broker role to which [it] had grown accustomed," see Taylor Dark, "Organized Labor and the Party Reform: A Reassessment," Polity 28 (Summer 1996): 512.

50. Jerome M. Rosow, "Memorandum for the Secretary, Subject: The Problem of the Blue-Collar Worker," April 16, 1970, Office of Secretary, James D. Hodgson, 1970 1971, General Records of Department of Labor, Record Group 174, NA. Charles Culhane, "White House Report," National Journal, January 30, 1971; Pete Hamil, "The Revolt of the White Lower-Middle Class," New Yorker, March 14, 1969. The Rosow report was inspired by Nixon's reading of Pete Hamil's 1969 New Yorker article outlining the growing problems of working Americans.

51. John R. Brown to George Schultz, 26 September 1970, box 39, Hodgson to Nixon, 25 August 1970, box 28, "Action Memo and Rosow Blue Collar Report, attachment B," box 39, all in Office of Secretary, James D. Hodgson, 1970 -1971, General Records of Department of Labor, Record Group 174, NA. The president assigned George Schultz, John Erlichman, and Attorney General John Mitchell to a working group to consider enacting aspects of the plan. Among the measures taken in line with the Rosow report were HUD's Operation Breakthrough, designed to "construct attractive homes at lower prices"; new safety and health standards for workers; the Higher Education Opportunity Act; the Urban Mass Transportation Assistance Act; and the Occupational Safety and Health Act.

52. Colson Memorandum, September 14, 1970, box 22, Staff Review Board Review of Contested Materials, White House Special Files, Colson, Nixon Presidential Materials, NA.

53. "Lots of Labor Cash for '70 Elections - And Where It's Going," U.S. News and World Report, October 19, 1970.

54. Haynes Johnson, "GOP Aimed Campaign Strategy at 'Wrong Group' Gallup Says," Washington Post, November 6, 1970. 
55. Jim Keogh to George Shultz, December 4, 1970, box 77, White House Special Files, Staff and Office Files, Charles Colson, Nixon Presidential Materials, NA.

56. "Campaign Wind-up: Pre-election Survey,” U.S. News and World Report, November $2,1970$.

57. AFL-CIO News, June 19, 1971; AFL-CIO News, January 9, 1971; George Meany, "The Economic Disaster," AFL-CIO American Federationist, August 1971.

58. AFL-CIO News, January 9, 1971.

59. Proceedings of the Ninth Constitutional Convention of the AFL-CIO, Bal Harbour, Florida, November 18 - 22, 1971 (Washington, DC: AFL-CIO, 1971), 13.

60. Paul McCracken to Hodgson, November 13, 1970, box 36, White House Central Files, Staff Member and Office Files, Herbert Stein, Nixon Presidential Materials, NA; New York Times, February 24, 1971. In line with McCracken's warning about wages, in February 1971 Nixon suspended the Davis-Bacon Act, which required that workers on public projects be paid at "prevailing wages." Meany blasted the suspension as "an open invitation to unscrupulous employers to exploit workers by competitive undermining of fair wage and labor standards."

61. AFL-CIO News, August 4, 1971; New York Times, August 20, 1971.

62. Abarca, "Discontented," 149; Safire, Before the Fall, 590.

63. "Nixon's Freeze and the Mood of Labor," Time, September 6, 1971.

64. Life, November 19, 1971; Time, September 6, 1971. Also see Newsweek, September 6, 1971; and Richard Nixon, RN: The Memoirs of Richard Nixon (New York: Grosset and Dunlap, 1978), 521. Meany was vindicated for his harsh stance against price and wage controls by none other than Nixon himself. In his memoirs, Nixon regretted the controls, writing that "the piper must always be paid, and there was an unquestionably high price for tampering with the orthodox economic mechanisms."

65. Gorman to Potofsky, May 6, 1971, box 3, Frank Rosenblum Papers, ACWA Archives, Kheel Center for Labor Documentation, Cornell University, Ithaca, NY.

66. Colson to Dwight Chapin, March 12, 1971, National Security Council Files, Name Files, box 828, Nixon Presidential Materials, NA.

67. "George Meany: Economic Chameleon," n.d., box 3, White House Special Files/Staff Member and Office Files, Desmond J. Baker, Nixon Presidential Materials, NA.

68. "Memorandum for the Files, Subject: Meeting with Messrs. Connally, Haldeman, Rumsfeld, Shultz, and Colson, 11/18 and 11/27 [1971]," box 28, Office of Secretary, 
James D. Hodgson, 1970 -1971, General Records of Department of Labor, Record Group 174, NA.

69. Allen J. Matusow, Nixon's Economy: Booms, Busts, Dollars, and Votes (Lawrence: University Press of Kansas, 1998), 196 - 97. The Pay Board - made up of five representatives from labor, five from business, and five representing the public interest regulated pay increases and ruled on appeals. Meany's resignation came with more than its share of Vietnam-related twists. He quit "to avoid any inference of complicity" in the board's decision to nullify a pay hike for West Coast longshoremen - a union ironically headed by Meany nemesis, antiwar activist, and suspected communist Harry Bridges. To protest the board's injunction, Bridges called upon his East Coast counterpart, the International Longshoremen Association (ILA), to join a national strike, halting shipping on both coasts smack in the middle of an election year. But to add further irony, the East Coast ILA determined, in view of Nixon's recent mining of Haiphong Harbor, that the hour was wrong for such a potentially costly strike. "Can you imagine us blockading U.S. ports at the very moment the president is blockading North Vietnam?" asked an ILA official.

70. Colson to Haig, April 21, 1972, box 828, National Security Council Files, Name Files, Nixon Presidential Materials, NA.

71. Haig to Colson, July 20, 1972, box 828, National Security Council Files, Name Files, Nixon Presidential Materials, NA.

72. Memorandum of Conversation, April 7, 1971, box 828, National Security Council Files, Name Files, Nixon Presidential Materials, NA.

73. Bunker to State, July 2, 1972, box 1435, Central Foreign Policy Files, 1970 -1973, Record Group 59, NA; "Board of Trustees Report, AAFLI, 1972,” 67/26, Meany Papers, GMMA.

74. AFL-CIO Executive Council Statement, "Storm Clouds over Asia," February 26, 1972. In addition to Vietnam, the statement lamented a "complete change of U.S. policy toward Communist China, stepped up withdrawal of American forces from Vietnam, the Indo-Pakistan war," and the expansion of Soviet military operations in the region.

75. Robinson, George Meany and His Times, 321. New York Times, January 26, 1972. The AFL-CIO already had gone on record as promising to support any Democrat running against Nixon.

76. “Conversation with Jay Lovestone," June 1, 1972, box 78, Colson Contested Materials, Nixon Presidential Materials, NA.

77. "Notes on McGovern," 77/29, Department of Legislation, GMMA.

78. “Conversation with Jay Lovestone," June 1, 1972, box 78, Colson Contested 
Materials, Nixon Presidential Materials, NA.

79. Economist, October 14, 1972.

80. Nixon, RN, 626; Haldeman, The Haldeman Diaries, 471, 487.

81. "Memorandum for the President," July 17, 1972, box 24, White House Special Files, Staff and Office Files, Charles Colson, Nixon Presidential Materials, NA.

82. Nixon, RN, 673.

83. Ehrlichman to Nixon, August 25, 1972, box 18, President's Office Files, President's Handwriting, Nixon Presidential Materials, NA.

84. Assistant Secretary of Defense, The Economics of Defense Spending: A Look at the Realities (Washington, DC: Department of Defense, 1972), 188. The DOD's politically inspired report, argued New York Times columnist James Reston, that those "who suggest that we can solve our spending problems by peeling some easy billions off of the defense budget are arguing not only with the Pentagon but with reality" (September 4, 1972). Reston reported that workers were deeply concerned about McGovern's proposed defense cut of $\$ 10$ billion over three years. Many workers, he wrote, "seem to think of the defense budget more in terms of job security than in terms of military security."

85. "Memorandum for the President, Subject: Meeting with Michael P. Balzano and Donald F. Rogers," June 12, 1972, box 24, White House Special Files, Staff and Office Files, Charles Colson, Nixon Presidential Material, NA. Working for Colson, Balzano focused primarily on patronage-related issues. After his election victory, Nixon appointed Balzano director of ACTION, the agency that resulted from the merger of the Peace Corps and VISTA programs. See "Statement Following Swearing in of Michael Balzano as Director of Action," May 10, 1970, Public Papers of the Presidents, Richard Nixon, 1973 (Washington, DC: U.S. Government Printing Office, 1975), 526.

86. Mason, Richard Nixon, 189.

87. George Gallop, "Blue Collar Workers - Key to McGovern's Problems, but Best Hope for Tuesday," box 100, White House Special Files, Staff and Office Files, Charles Colson, Nixon Presidential Material, NA. "Missing Coattails," Time, November 20, 1972.

88. "Continuity of U.S. Leadership,” U.S. News and World Report, November 20, 1972.

89. Nixon to Meany, February 1, 1973, 76/21, Meany Papers, GMMA.

90. Ken Cole to Ford, n.d., box 51, White House Central Files, Subject Files, PR 7 - 1, Gerald R. Ford Library, Ann Arbor, MI. Meany never fully trusted Brennan, whom he 
suspected of grandstanding during the hard-hat protests. Resentful of Brennan's continuing support for Nixon as the economy crumbled and possibly considering him a rival, Meany, by 1973, refused to meet with the secretary. Regarding Brennan's unsatisfying tenure as secretary of labor, see Thomas R. Mullaney, "A Populist in the Nixon Cabinet," New York Affairs 2 (1975): 50 - 59.

91. Scholarship that links the 1972 election to the later Reagan Democrats includes Edsall and Edsall, Chain Reaction, 21; John Micklethwait and Adrian Wooldridge, The Right Nation: Conservative Power in America (New York: Penguin, 2004), 10; James MacGregor Burns and Georgia J. Sorenson, Dead Center: Clinton-Gore Leadership and the Perils of Moderation (New York: Simon and Schuster, 1999), 151; Arthur C. Paulson, Realignment and Party Revival: Understanding American Electoral Politics at the Turn of the Twentyfirst Century (New York: Praeger/Greenwood, 2000), 243.

92. Kotlowski, "Black Power," 411 - 12, points, for instance, to Nixon's ironic appreciation for Black Power ideals.

93. For particularly sharp critiques of identity politics see Todd Gitlin, Twilight of Common Dreams, 126 -41; Jim Sleeper, Liberal Racism: How Fixating on Race Subverts the American Dream (New York: Rowman and Littlefield, 1997), 11 - 12; and Michael Lind, The Next American Nation: New Nationalism and the Fourth American Revolution (New York: Free Press, 1995), 101. For a different perspective on the limits of identity politics see Eric Lott, "After Identity Politics: The Return of Universalism," New Literary History 31 (2000): $665-80$. 